\title{
Erratum to: Factors Controlling Pre-Columbian and Early Historic Maize Productivity in the American Southwest, Part 2: The Chaco Halo, Mesa Verde, Pajarito Plateau/Bandelier, and Zuni Archaeological Regions
}

\section{Larry V. Benson}

Published online: 19 June 2010

(C) Springer Science+Business Media, LLC 2010

\section{Erratum to: J Archaeol Method Theory DOI 10.1007/s10816-010-9083-y}

The original version of this article unfortunately contained a mistake.

p. nnn: Columns labeled 'bu/ac' should read ' $\mathrm{g} \mathrm{NO}_{3}$ ' in Table 10.

In the explanation written below Table 10, 'bu/ac indicates the number of bushels of maize that could be supported in the first year of plant growth' should read ' $\mathrm{g} \mathrm{NO}_{3}$ indicates the amount of nitrate produced within the root zone during the first year of plant growth.'

p. mmm: Columns labeled 'bu/ac' should read ' $\mathrm{g} \mathrm{NO}_{3}$ ' in Table 11.

The first sentence of the explanation written below Table 11 should read ' $6.6 \mathrm{~g}$ of $\mathrm{NO}_{3}-\mathrm{N}$ is needed to produce $7 \mathrm{bu} / \mathrm{ac}$ of maize planted at a hill spacing of $2.4 \mathrm{~m}$ and an average hill density of 2 plants.'

In the explanation written below Table 11, 'bu/ac indicates the number of bushels of maize that could be supported in the first year of plant growth' should read ' $\mathrm{g} \mathrm{NO}$ indicates the amount of nitrate produced within the root zone during the first year of plant growth.'

The online version of the original article can be found at http://dx.doi.org/10.1007/s10816-010-9083-y.

L. V. Benson $(\bowtie)$

National Research Program, U.S. Geological Survey, 3215 Marine St., Boulder, CO 80303, USA

e-mail: lbenson@usgs.gov 